\title{
Audit Committee Effectiveness, Audit Quality and Earnings Management: An Empirical Study of the Listed Companies in Egypt \\ Mohamed M. Soliman ${ }^{1 *}$ and Aiman A. Ragab ${ }^{2}$
}

1. Arab Academy for Sciences \&Technology, College of Management \&Technology, Egypt

2. Arab Academy for Sciences \&Technology, College of Management \&Technology, Egypt

* E-mail of the corresponding author: Mohamed.soliman@aast.edu

\begin{abstract}
The role of audit committees and audit quality in ensuring the quality of corporate financial reporting has come under considerable scrutiny due to recent high-profile earnings management cases in the world. The purpose of this paper is to examine the association between the audit committee effectiveness, audit quality and earnings management practices of more active 50 Egyptian companies listed on the Egyptian Stock Exchange of the nonfinancial sector during the period 2007-2010. After controlling for size, leverage and cash flow from operation activities, the results of univariate and multivariate analyses indicated that audit committees independence; experience of audit committee members; audit committee meetings; and audit quality have significant negative association with discretionary accruals as a proxy for earnings management. On the other hand, no significant relationship is found between audit committees size and the level of discretionary accruals. This paper is important because it offers useful information that is of great value to policy makers, academics and other stakeholders.
\end{abstract}

Keywords: Audit Committee Effectiveness, Audit Quality, Earning Management, Egypt

\section{Introduction}

The end of the 1990s and the beginning of 21 st century have witnessed a series of corporate accounting scandals across the United States and Europe. Examples include Enron, Parmalat, Tyco, WorldCom and Xerox. At the core of these scandals was usually the phenomenon of earnings management (Goncharov, 2005). Earnings management has been a great and consistent concern among practitioners and regulators and has received considerable attention in the accounting literature. It has been argued that earnings management masks the true financial results and position of businesses and obscures facts that stakeholders ought to know (Loomis, 1999).

The effectiveness of audit committees has been a subject of increasing interests due to increased concerns about the quality of corporate financial reporting process caused by recent accounting scandals. Abbott et al., (2004) report that an audit committee that is independent, meets at least four times a year, and includes at least one member with financial expertise is negatively associated with the occurrence of earnings management.

Also, the role of auditing in ensuring the quality of reported earnings has come under considerable scrutiny due to recent corporate accounting scandals (Balsam et al., 2003). The agency problems associated with the separation of ownership and control, along with information asymmetry between management and absentee owners, create the demand for external audit. External auditors are responsible for verifying that the financial statements are fairly stated in conformity with GAAP and that these statements reflect the 'true' economic condition and operating results of the entity. Thus, the external auditor's verification adds credibility to the company's financial statements. Therefore, a quality audit is expected to constrain opportunistic earnings management (Lin \& Hwang, 2010).

In Egypt, several mechanisms was adopted in the last decade, which aims to increase levels of transparency and confidence in the content of financial reporting, these mechanisms include Egyptian Accounting Standards, and the code of corporate governance $(2005,2011)$, and the creation of the Egyptian Financial Supervisory Authority (EFSA). In spite of all this mechanisms, the ability of companies to manipulate financial reports through the earnings management still exists, especially since these management practices are legally and within the flexibility allowed by the accounting standards which differ from illegal practices and that are classified as cases of fraud (Metawee, 2013).

Empirical evidences on the effect of audit committee effectiveness and audit quality on the occurrence of earnings management is rather inconsistent. Also, there has so far been relatively little or no research into 
earnings management practices in Egypt (Kamel \& Elbana, 2012). The multi-cultural roots of Egyptian society make it different from other societies and hence distinguish it as a setting for this study. Therefore, the purpose of this paper is to examine the association between the audit committee effectiveness, audit quality and earnings management practices of more active 50 Egyptian companies listed on the Egyptian Stock Exchange of the nonfinancial sector during the period 2007-2010.

This study provides many recommendations to the regulatory authorities in Egypt regarding ways to strengthen and reinforce audit committee effectiveness and audit quality. Also, this study is the first to include several variables related to audit committee effectiveness and audit quality that have been shown to have a strong effect on the quality of reported earnings in Egyptian companies.

This study proceeds as follows. The next section provides a literature review and development of hypothesis. Section three describes the methodology, and the data. Section four reports the empirical results and the robustness checks. Finally, section five concludes the study.

\section{Literature Review and Development of Hypothesis}

Various definitions exist for earnings management. Schipper (1989) appears to have captured the essence of earnings management by defining it as "purposeful intervention in the external financial reporting process with the intent of obtaining private gain". Likewise, Healy \& Wahlen (1999) state that "earnings management occurs when managers use judgment in financial reporting and in structuring transactions to alter financial reports to either mislead some stakeholders about the underlying economic performance of the company or to influence contractual outcomes that depend on reported accounting numbers". Regardless of the definition adopted, earnings management is inherently unobservable.

Opportunistic earnings management practice produces less reliable accounting earnings that do not reflect a firm's financial performance. Earnings management is likely to reduce the quality of reported earnings and its usefulness for investment decisions, thus reducing investor confidence in the financial reports. However, accounting earnings are more reliable and of higher quality when managers, opportunistic behaviour is reduced using monitoring systems (Wild, 1996; and Dechow et al., 1996). Thus, stock market regulators and other investor protection agencies are concerned about earnings management, especially after the collapse of several large firms in recent decades and they have responded by enhancing audit committee effectiveness and audit quality.

Empirical evidences on the effect of audit committee effectiveness and audit quality on the occurrence of earnings management is rather inconsistent. Therefore, the purpose of this paper is to examine the association between the audit committee effectiveness, audit quality and earnings management practices.

\subsection{Audit Committee Effectiveness and Earning Management}

An audit committee plays an important monitoring role to assure the quality of financial reporting and corporate accountability (Carcello \& Neal, 2003). As a liaison between the external auditor and the board, an audit committee bridges the information asymmetry between them, facilitates the monitoring process, and enhances the independence of an auditor from management (Klein, 2002). A properly functioning audit committee is thus critical in enhancing effective oversight of the financial reporting process and achieving high quality financial controls.

Since the value of a firm is linked to reported earnings figures, it creates economic incentives or pressures for management to engage in earnings management. According to the Blue Ribbon Committee (BRC, 1999) report, audit committee report serves as an ultimate monitor of the financial reporting system; the committee selects the outside and question management, external auditor and internal auditor to determine whether they are acting in the best interest of the company. One of the primary function of the audit committee is to safe cards the independence of external auditor, given the strong economic or personnel affiliation of inside directors with the company or its management. Audit committees that have a majority of affiliated directors will be more likely to side with management in any disputes with the auditor (Ebrahim, 2007). In addition Klein (2002) finds that an independent audit committee and active audit committee are associated with lower levels of discretionary, earning management is negatively associated with a committee composed only of independent directors, that meet more than twice a year .(Siregar \& Utama, 2008). It is expected, therefore, that good characteristics of 
audit committees are associated with good company financial performance, which in turn, are negatively associated with the earnings management.

Apart from the benefit that is gained from the audit committee establishment, previous studies suggested that audit committee size; the independence of members; expertise; and meeting frequency of audit committees impact their monitoring effectiveness (DeZoort \& Salterio, 2001; Klein, 2002; Siregar \& Utama, 2008; and Metawee, 2013). This study will examine the audit committee effectiveness on earnings management by examine the effect of audit committee size; the independence of members; expertise; and meeting frequency of audit committees on earnings management.

\subsubsection{Audit Committee Size and Earnings Management}

The number of audit committee members is used as an indication of resources available to this committee (Lin, et al., 2006). Some studies, such as those of Jensen (1993) and Yermack (1996), suggest that the number of members on an audit committee affects its decisions. Bédard et al., (2004) argue that the larger the audit committee, the more likely it is to uncover and resolve potential problems in the financial reporting process because it is likely to provide the necessary strength and diversity of views and expertise to ensure effective monitoring. Empirical studies provide mixed evidence of the impact of audit committee size on financial reporting quality. Xie et al., (2003) find no significant association between the number of directors on the audit committee and earnings management. Similarly, Abbott et al., (2004) find no impact of audit committee size on earnings restatement. On the other hand, Yang \& Krishnan (2005) find that audit committee size is negatively associated with earnings management, implying that a certain minimum number of audit committee members may be relevant to quality of financial reporting.

The Egyptian Corporate Governance Code $(2005,2011)$ suggests that the minimum number of audit committee members should be three directors. Accordingly, Based on the above discussion, the following hypothesis is developed:

\section{H1. There is a significantly negative association between audit committee size and the occurrence of earnings restatement.}

\subsubsection{Independence of Audit Committee Members and Earning Management}

An audit committee should be independent from management in order to be able to conduct effective monitoring, resulting in less opportunistic management behaviour, such as earnings management. The quality and credibility of financial reporting can be badly affected when the audit committee has low or no independence (Lin, et al., 2006). Independence of audit committee members has been the focus of most of the prior work. A common expectation is that independent audit committee directors would ensure better financial reporting (SEC, 2003), and the expectation is generally supported by existing empirical evidence (Abbott et al., 2000; and Beasley et al., 2000). Specifically, Abbott et al., (2004) document a negative association between occurrence of earnings restatement and audit committee consisting of only independent directors. Similarly, Choi et al., (2004) find that, when members of the audit committee hold shares in their firm, they are less effective in mitigating earnings management. Thus, the independence of the audit committee is a key factor in enhancing its role in preventing mis-statements in the financial statements.

In Egypt, the Corporate Governance Code $(2005,2011)$ encourages the establishment of an audit committee to facilitate improving the quality of Egyptian financial reporting. With regard to the composition of the audit committee, the Code further requires that independent directors should be in majority. Accordingly, Based on the above discussion, the following hypothesis is developed:

H2. There is a significantly negative association between audit committee independence and the occurrence of earnings restatement.

\subsubsection{Audit Committee's Financial Expertise and Earning Management}

Audit committees with financial expertise are important as they show support for auditors (DeZoort et al., 2003; DeZoort \& Salterio, 2001), the credibility of the financial statement (Burrowes and Hendriks, 2005), and the high quality of reported earnings (Choi et al., 2004). DeZoort \& Salterio (2001) argue that the audit committee's financial expertise increases the likelihood that detected material misstatements will be communicated to the 
audit committee and corrected in a timely fashion. Choi et al., (2004), Abbott et al., (2004), and Bédard et al., (2004) show that the presence of at least one member with financial expertise sitting on the audit committee is negatively related to the level of earnings management.

In Egypt the Corporate Governance Code $(2005,2011)$ stating that, "The board should satisfy itself that at least one member of the audit committee has recent and relevant financial experience". But The Code does not define a financial expert as someone who has a professional qualification from one of the professional accountancy bodies. To examine the relationship between the audit committee's financial expertise and earnings quality, this study tests the H3:

\section{H3. There is a significantly negative association between the audit committee's financial expertise and the} occurrence of earnings management

\subsubsection{Audit Committee Meetings and Earnings Management.}

Effective audit committees meet regularly to ensure that the financial reporting process is functioning properly, and therefore a well-functioning and active audit committee may be able to prevent earnings management. An important objective for an audit committee is to provide its members with sufficient time to perform their duties of monitoring their firm's financial reporting process (Lin \& Hwang, 2010). Menon and Williams (1994) find that audit committee effectiveness can be measured by the number of audit committee meetings. The number of meetings is used in prior research because inactive audit committees are unlikely to monitor management effectively (Menon \& Williams, 1994). The prior research provides inconsistent evidence on the issue. For example, Lin et al., (2006) and Xie et al., (2003) report a negative association between earnings management and the number of audit committee meetings. In contrast, Bédard et al., (2004), and Yang \& Krishnan (2005) fail to find such an association. Based on the above discussion, the following hypothesis is developed:

\section{H4. There is a significantly negative association between audit committee meetings and the occurrence of earnings management.}

\subsection{Audit Quality and Earning Management}

In a capital market where financial reports are a key feature of communication with respect to public firms' performance and financial position, the auditor is perceived as an effective third party who helps mitigate information asymmetry and conflict of interests between management and investors. Mansi, et al., (2004) identify two roles of an auditor: the information role and the insurance role. As an information intermediary, an auditor is a person who independently and effectively verifies the correctness of company's financial statements before they are published. As an insurance provider, on the other hand, an auditor is a person who is legally accountable for damages to financial statement users. Auditors therefore carry out primary responsibility for promoting transparency in financial reporting processes that in turn generate high quality financial statements. In other words, auditors are one of the key drivers that help promote the transparency of the stock markets.

The literature recognizes that the Big four auditors provide higher quality audits and offer greater reliability to clients' financial statements than the non-Big 4 auditors. Krishnan (2003) demonstrate that Big 4 auditors are better at constraining client earnings management compared to non-Big 4 auditors; they find that clients of nonBig 4 auditors have higher levels of discretionary accruals. In the same context, Ahsen (2011) find that Big 4 auditors associate with less earnings management in the firms. Indeed, Big 4 audit companies are assumed to have higher audit quality than non-Big 4, because they are less dependent on their clients. Similarly, Francis and Yu (2009) and Choi et al., (2010) have shown that audit office size is a primary determinant of audit quality. Also, Craswell et al., (1995) document that clients of the Big 4 auditors have lower total values of discretionary. Thus, based on prior findings that Big 4 auditors limit their clients' ability to manage earnings through accruals, we expect that their clients will chose to more real earnings management given motivations to manage earnings. This leads to the following hypothesis:

H5: There is a significantly negative association between audit quality and the occurrence of earnings management. 


\subsection{Audit Committees and Auditing Profession in Egypt}

In Egypt, the formation of an audit committee has been the main focus of the government since the early $1990 \mathrm{~s}$. However, the formation of audit committee was only on a voluntary basis. It was only in 2000 that the formation of an audit committee was made mandatory for all companies listed on The Egyptian exchange (the executive regulations of Act No. 93 for the year 2000). The inclusion of the formation of an audit committee as one of the Egyptian exchange listing requirements is complementary with the government initiatives to strengthen the corporate governance of all listed companies in Egypt. The Egyptian financial supervisory authority (EFSA), which was established in 2009, is responsible for regulating the market and ensuring good governance practices among listed companies. As part of the listing requirements, the practice of corporate governance must be disclosed in annual reports of listed companies (Metawee, 2013).

The country started to develop a Corporate Governance Code only in 2005 and the audit committee section is not more than a page. The most important elements discussed in the codes in relation to audit committees are: The audit committees should be comprised from non-executive Board of Directors members but with a minimum of three, with an option of hiring members from outside of the company. There should be at least one member as a financial expert. The General Assembly should issue, upon a recommendation from the Board of Directors, a manual for hiring audit committee members and determine their duration, responsibilities and remuneration. The management should provide audit committee with all available resources and help to conduct its responsibilities including appointment of external advisors and counsels.

Regarding auditing profession, Egypt has a combined structure of the auditing firms. All the major international auditing firms have a presence in Egypt in addition to well-established local auditing firms. It might be expected that international auditing firms working in Egypt would be more familiar with IAS including parts of the IAS which are not publicly available in Arabic. As a result, it is expected that Egyptian companies audited by one of the international auditing firms will comply more closely with the IAS. KPMG, Ernst and Young, Deloitte Touche Tohmatsu, and Price Waterhouse Coopers are the major international accountancy and legal firms with local partnership.

Almost all ISA are applicable in Egypt. Auditors are required to follow the six Egyptian auditing standards that relate to an auditor's report, and any ISA that relates to other aspects of the auditing process. Knowledge deficiencies of most practitioners by ISA in practice restrict ensuring sound auditing practice. Although large auditing firms have greater competence to provide high auditing quality, compliance with the applicable auditing standards is not always ensured: in this respect the large firms differ from the small firms. Abd-Elsalam \& Weetman (2003) noticed in Egypt that international auditing firms, in most cases, stated that the financial statements were prepared according to the IAS. In many cases, international auditing firms referred to compliance with IAS, but not the ISA. In contrast, local auditing firms, in most cases, stated that the financial statements were prepared according to Generally Accepted Accounting Principles (GAAP) without giving any further explanation of what the phrase meant.

\section{Methodology \\ 3.1: Sample selection}

The sample in the current study consists of the Egyptian companies from amongst the top 50 most active-traded companies listed in the Egyptian Stock Exchange over the period 2007-2010. financial companies; e.g. banks, insurance companies, and leasing companies; were excluded from the sample due to the different requirements of disclosure and corporate governance. Hence their annual reports may be not comparable to those of other companies. This gave us a sample of 40 firms. As no relevant Data Stream exists in Egypt, the annual reports, covering the four year period 2007-2010, were purchased from the Egyptian Company for Information Dissemination (EGID) to extract the information on the variables needed to test each of the research hypotheses.

\subsection{The proxy for earnings management: dependent variable}

Consistent with prior research, we use discretionary accruals as a proxy for financial misrepresentation or earnings management. Most prior literature uses Modified Jones (1991) model because it was found to be superior to other extant methods at the time in detecting abnormal accruals i.e. discretionary accruals (Dechow \& Skinner, 2000). Discretionary accruals (DA) are defined as the difference between total accruals (TA) and non- 
discretionary accruals (NDA). In order to find discretionary accruals we calculated first of all total accruals (TA) as follows (Collins \& Hriber, 2002; and Shah et al., 2009):
TAt $=$ N.It - CFOt
Eq. (1)

Where: TAt, is total accrual in year t.; N.It, is Net Income in year t; and CFOt, is cash flows from operating activities in year $\mathrm{t}$.

Second, we calculated non-discretionary accruals (NDA) as follows (Johari et al., 2008 and Shah et al., 2009):

$$
N D A_{t}=\alpha 1\left(\frac{1}{A_{t-1}}\right)+\alpha 2\left(\frac{\Delta R E V_{t}-\Delta R E C_{t}}{A_{t-1}}\right)+\alpha 3\left(\frac{\Delta P P E_{t}}{A_{t-1}}\right)+\varepsilon \quad \text { Eq. (2) }
$$

Where: $\triangle \mathrm{REV} t$ is revenues in year $\mathrm{t}$ less revenue in year $\mathrm{t}-1 ; \triangle \mathrm{RECt}$ is net receivables in year $\mathrm{t}$ less net receivable in year $\mathrm{t}-1 ; \triangle \mathrm{PPEt}$ is gross property plant and equipment at the end of year $\mathrm{t}$; At-1 is total assets at the end of year $\mathrm{t}-1 ; \alpha 1, \alpha 2, \alpha 3$ are firm specific parameters; and $\varepsilon$ is the residuals.

Finally, we calculated discretionary accruals (DAC) as a proxy for earnings management as follows (Shah et al., 2009):

$$
\text { DACt }=\text { TAt }- \text { NDAt }
$$

Where: DACt, is discretionary component of accruals in year $t$; TAt, is total accrual in year $t$; and NDAt, is nondiscretionary accruals in year $\mathrm{t}$.

\subsection{Independent variables}

The explanations of dependent; independents; and control variables are presented in Table 1. Most measurements and expected relations are consistent with prior researches (Klein, 2002; Piot \& Janin, 2007; Peasnell et al., 2005; and Metawee, 2013).

\begin{tabular}{|c|c|c|c|}
\hline Variables & $\begin{array}{l}\text { Indicator } \\
\mathrm{S}\end{array}$ & $\begin{array}{l}\text { Expecte } \\
\text { d Signs }\end{array}$ & Measurement \\
\hline \multicolumn{4}{|l|}{ Dependent Variable } \\
\hline Discretionary Accruals & DAC & & Measured by the modified Jones model. \\
\hline \multicolumn{4}{|l|}{ Independent Variables } \\
\hline Audit Committee Size & ACSIZE & - & $\begin{array}{l}\text { It is a total number of audit committee } \\
\text { members. }\end{array}$ \\
\hline $\begin{array}{l}\text { Audit Committee } \\
\text { Independence }\end{array}$ & ACIND & - & $\begin{array}{l}\text { An indicator variable equal to " } 1 \text { " if all } \\
\text { the audit committee members are } \\
\text { independent, " } 0 \text { " otherwise. }\end{array}$ \\
\hline $\begin{array}{l}\text { Audit Committee } \\
\text { Member's Expertise }\end{array}$ & ACEXP & - & $\begin{array}{l}\text { An indicator variable equal to " } 1 \text { " if at } \\
\text { least one of the audit committee members } \\
\text { is a financial expert, and " } 0 \text { " otherwise. }\end{array}$ \\
\hline $\begin{array}{l}\text { Audit Committee } \\
\text { Meetings }\end{array}$ & ACMET & - & $\begin{array}{l}\text { Number of meetings of audit committees } \\
\text { per year. }\end{array}$ \\
\hline Audit Quality & AUQUL & - & $\begin{array}{l}\text { An indicator variable equal to " } 1 \text { " if the } \\
\text { auditor is a Big- } 4 \text { firm, and " } 0 \text { " otherwise. }\end{array}$ \\
\hline \multicolumn{4}{|l|}{ Control Variables } \\
\hline Firm size & FISIZE & - & Natural log of total assets. \\
\hline Financial Leverage & FLEV & + & Debt-to-assets ratio \\
\hline $\begin{array}{l}\text { Cash Flows from } \\
\text { Operating Activities }\end{array}$ & CFO & - & $\begin{array}{l}\text { Cash flows from operating activities } \\
\text { divided by total assets at the beginning of } \\
\text { the period. }\end{array}$ \\
\hline
\end{tabular}

Table 1: Dependent; Independents and Control Variables

\subsection{Control Variables}

In addition to the independent variables discussed above, a number of control variables are included in this study to control for firm characteristics that can influence the occurrence of earning management. Large firms face 
greater political costs relative to their small counterparts. However, Meek et al., (2007) argue that earnings management may be lower in large firms because, compared to other firms they have lower information asymmetry, stronger governance structures and stronger external monitoring. Also, empirical research documents that firms with financing needs and firms approaching debt covenant default triggers have higher levels of abnormal accruals, a higher incidence of GAAP violation and a higher likelihood of committing accounting fraud (Weber, 2006). The larger the firm is leveraged, the more likely managers are to choose income decreasing. We use debt-to-assets ratio (LEV) to proxy for the effects of debt covenants on earnings management (Peasnell et al., 2005). This study also controls for the effect of cash flows from operating activities (CFO) to capture performance differences across firms in different industries and to control for the effect of economic activity on earnings management. Jiang et al., (2008) note that firms with a strong operating cash flow performance are less likely to manage discretionary accruals upwards because they are already performing well. Conversely, firms with a low operating cash flow are more likely to manage discretionary accruals downwards. Dechow et al., (1995) shows that CFO influences the magnitude of discretionary accruals, and higher CFOs are associated with lower discretionary accruals. Consistent with prior research, such as that of Peasnell et al., (2005), this study defines CFO as cash flows from operating activities divided by total assets at the beginning of the period.

\subsection{Model specification}

To test our hypotheses, we utilize the following logistic regression model, where the dependent variable is (DAC). The independent variables are (ACSIZE); (ACIND); (ACEXP); (ACMT) for audit committee effectiveness and (AUQUL) for audit quality. The other variables in the model are included to control for factors related financial characteristics of the firms that may influence management's decision to manage or manipulate reported earnings:

$$
\begin{aligned}
\text { DAC }= & \beta 0+\beta 1 \text { ACSIZE }+\beta 2 \text { ACIND }+\beta 3 \text { ACEXP + } 44 \text { ACMT + } 35 \text { AUQUL } \\
& +\beta 6 \text { FISIZE }+\beta 7 \text { FLEV }+\beta 8 \text { CFO + } \varepsilon
\end{aligned}
$$

Where: DAC, discretionary accruals; ACSIZE, audit committee size; ACIND, audit committee independence; ACEXP, audit committee member's expertise; ACMT, audit committee meetings; AUQUL, audit quality; FISIZE, firm size; FLEV, financial leverage; CFO, cash flows from operating activities; and $\boldsymbol{\varepsilon}$, the error term.

\section{Results and Discussion}

\subsection{Descriptive Statistics}

Table 2 provides the mean, median and standard deviation of the variables in the study. The results reveal that average DAC stood at -0.9875 , while the median is 3.0176 from prior year's total assets. With regard to audit committees size, the results indicate that the mean size for audit committee at 4.69 members consistent with Raghunandan \& Rama (2007). Also, it appears from Table 2 regarding the composition of audit committees, that the average ratio of independent directors is (79\%). As shown in table 2, about $58 \%$ of audit committees in this study meet the Egyptian $(2005,2011)$ Corporate Governance Code's requirement of having at least one financial expert as a member of the audit committee. The average number of audit committee meetings in this sample is 4.94; this result is consistent with previous findings by Xie et al., (2003) and Metawee, (2013). Also, results reveal that $(31 \%)$ of companies sampled are audited by the big 4 audit firms.

Table 2. Descriptive statistics for study variables

\begin{tabular}{|l|c|c|c|c|}
\hline \multicolumn{1}{|c|}{ Variable } & Label & Mean & Median & Std. Deviation \\
\hline discretionary accruals & DAC & -0.9875 & 3.0176 & 7.87658 \\
Audit Committee Size & ACSIZE & 4.6944 & 3.8758 & 2.40023 \\
Audit Committee Independence & ACIND & 0.7952 & 0.6841 & 4.86532 \\
Audit Committee Member's Expertise & ACEXP & 0.5856 & 0.48691 & 0.50395 \\
Audit Committee Meetings & ACMT & 4.9444 & 4.0196 & 2.75623 \\
Audit Quality & AUQUL & 0.3196 & 2.6952 & 0.46790 \\
Firm Size & FISIZE & 13.928 & 11.9384 & 2.60871 \\
Financial Leverage & FLEV & -0.9123 & -0.9010 & 4.05437 \\
Cash Flows from Operating Activities & CFO & 0.1079 & 0.0846 & 0.07614 \\
\hline
\end{tabular}




\subsection{Correlation matrix and multicollinearity analysis}

Multicollinearity in explanatory variables has been diagnosed through analyses of correlation factors and Variable Inflation Factors (VIF). Table 3 presents the correlation matrix of the variables used in the study, from which, it has been observed that the highest simple correlation between independent variables was 0.784 between auditor committee independence (ACIND) and audit quality (AUQUL). Bryman \& Cramer (1997) suggest that simple correlation between independent variables should not be considered harmful until they exceed 0.80 or 0.90 . This confirms that there is no multicollinearity among the variables. The further confirmation of mutlitolinearity assumption is checked by variance inflation factor (VIF). The (VIF) in excess of 10 should be considered an indication of harmful multicollinearity (Neter et al., 1989). Alternatively, if the average VIF is substantially greater than 1 then the regression may be biased (Bowerman \& O'Connell, 1990). Table 4 shows that the average VIF (1.17) is close to 1 and this confirms that collinearity is not a problem for this model. These findings suggest that multicollinearity between the independent variables is unlikely to pose a serious problem in the interpretation of the results of the multivariate analysis.

\subsection{Multivariate analysis}

As in many previous disclosure studies, regression analysis has been preferred to investigate the association between effectiveness of audit committees and audit quality on the occurrence of earnings management of Egyptian companies. Results of an Ordinary Least Square (OLS) regression in Table 4 show that the F-ratio is $10.65(\mathrm{P}=0.00)$. The result statistically supports the significance of the model. The value obtained for the adjusted coefficient of determination $\mathrm{R}$ square of the model was .634. This tells us how much of the variance in the dependent variable (occurrence of discretionary accruals) is explained by the model. Given these results, the study concludes that the variables considered in the model largely explain the occurrence of discretionary accruals.

Table 3. Correlation coefficients Matrix of the variables used in the study:

\begin{tabular}{|c|c|c|c|c|c|c|c|c|c|}
\hline $\begin{array}{l}\text { Variabl } \\
\text { e }\end{array}$ & DAC & $\begin{array}{c}\text { ACSIZ } \\
\text { E }\end{array}$ & $\begin{array}{c}\text { ACIN } \\
\text { D }\end{array}$ & ACEXP & ACMT & $\begin{array}{c}\text { AUQU } \\
\text { L }\end{array}$ & $\begin{array}{c}\text { FISIZ } \\
\text { E }\end{array}$ & FLEV & CFO \\
\hline DAC & 1 & & & & & & & & \\
\hline $\begin{array}{c}\text { ACSIZ } \\
\text { E }\end{array}$ & $\mathbf{- 0 . 0 1 6}$ & $\mathbf{1}$ & & & & & & & \\
\hline ACIND & $\mathbf{- 0 . 4 7 2}$ & $\mathbf{0 . 0 2 2}$ & 1 & & & & & & \\
\hline ACEXP & $\mathbf{- 0 . 5 0 8}$ & $\mathbf{0 . 0 8 2}$ & $\mathbf{0 . 0 8 1}$ & 1 & & & & & \\
\hline ACMT & $\mathbf{- 0 . 3 8 5}$ & $\mathbf{- 0 . 0 1 9}$ & $\mathbf{0 . 0 1 0}$ & $\mathbf{- 0 . 0 4 7}$ & 1 & & & & \\
\hline $\begin{array}{c}\text { AUQU } \\
\text { L }\end{array}$ & $\mathbf{- 0 . 4 7 2}$ & $\mathbf{0 . 2 0 9}$ & $\mathbf{0 . 7 8 4}$ & $\mathbf{0 . 0 2 8}$ & $\mathbf{0 . 0 3 2}$ & 1 & & & \\
\hline FISIZE & $\mathbf{0 . 5 4 7}$ & $\mathbf{0 . 2 5 0}$ & $\mathbf{0 . 1 8 9}$ & $\mathbf{0 . 0 2 3}$ & $\mathbf{- 0 . 0 0 6}$ & $\mathbf{0 . 4 2 8}$ & 1 & & \\
\hline FLEV & $\mathbf{- 0 . 1 1 6}$ & $\mathbf{0 . 0 1 2}$ & $\mathbf{- 0 . 0 0 6}$ & $\mathbf{- 0 . 0 2 6}$ & $\mathbf{- 0 . 0 3 6}$ & $\mathbf{0 . 5 5 5}$ & $\mathbf{- 0 . 1 1 1}$ & 1 & \\
\hline CFO & $\mathbf{- 0 . 2 6 5}$ & $\mathbf{0 . 1 1 4}$ & $\mathbf{0 . 0 4 0}$ & $\mathbf{- 0 . 0 0 6}$ & $\mathbf{- 0 . 0 3 3}$ & $\mathbf{0 . 4 8 7}$ & $\mathbf{0 . 2 7 2}$ & $\mathbf{0 . 1 7 7}$ & 1 \\
\hline
\end{tabular}

\subsection{Results of Regression Model}

Table 4 reports the multivariate logistic regression results. The H1 states that there is a significantly negative association between audit committee size and occurrence of earnings management. As shown in Table 3 and 4 , this hypothesis is not supported. No significant relationship is found between audit committees size (ACSIZE) and the level of discretionary accruals (coefficient $=-0.016$ and $\mathrm{p}>0.05$ ). However, although no statistically significant relationship is detected, a negative directional sign of the coefficient is observed. This result may support the argument that larger audit committees do not significantly enhance the quality of financial reporting. This result is similar to that of the vast majority of studies, such as those of Xie et al., (2003), Abbott et al., (2004), and Bédard et al., (2004) that examine the effect of audit committee's size on earnings management, and fail to find a significant impact of audit committee size on earnings management.

The $\mathrm{H} 2$ states that there is a significantly negative association between audit committee independence (ACIND) and occurrence of earnings management. As shown in Table 3 and 4, this hypothesis is supported (coefficient = 0.472 and $\mathrm{p}<0.05$ ). This is consistent with prior studies, such as those of Beasley (1996); and Piot and Janin (2007) that empirically find that audit committee independence is strongly associated with lower levels of earnings management. Also, the H3 states that the financial expertise of audit committee (ACEXP) is significantly negatively associated with occurrence of earnings management. The result presented in Table 3 and 
4 is supported this hypothesis (coefficient $=-0.508$ and $\mathrm{p}<0.05$ ). The result suggests that audit committees that include at least one member with financial expertise are likely to discourage management from manipulating the earnings figures in annual reports. This result is also consistent with the vast majority of the previous research that investigates the effect of financial experts on earnings management, such as that of Choi et al., (2004); Park \& Shin (2004); Carcello \& Neal (2003); Chen et al., (2005); and Metawee, (2013).

Table 4. Regression results

\begin{tabular}{|c|c|c|c|c|}
\hline \multicolumn{5}{|c|}{$\begin{array}{c}D A C=\beta 0+\beta 1 A C S I Z E+\beta 2 A C I N D+\beta 3 A C E X P+\beta 4 A C M T+\beta 5 A U Q U L \\
+\beta 6 \text { FISIZE }+\beta 7 F L E V+\beta 8 C F O+\varepsilon\end{array}$} \\
\hline Variable & $\beta$ & t-value & Sig. & VIF \\
\hline Constant & 4.431 & 3.897 & 0.000 & \\
\hline ACSIZE & 2.897 & 3.197 & 0.287 & 1.08 \\
\hline ACIND & 0.046 & .726 & 0.024 & 1.07 \\
\hline ACEXP & -0.358 & -0.272 & 0.001 & 1.23 \\
\hline ACMT & -0.288 & 1.153 & 0.207 & 1.29 \\
\hline AUQUL & -1.863 & 0.194 & $\mathbf{0 . 0 3 8}$ & 1.17 \\
\hline FISIZE & 7.976 & 1.727 & 0.000 & 1.18 \\
\hline FLEV & -0.214 & 0.040 & 0.000 & 1.10 \\
\hline CFO & 0.044 & 2.398 & $\mathbf{0 . 0 1 4}$ & 1.24 \\
\hline \multicolumn{5}{|c|}{ Model Summary } \\
\hline $\boldsymbol{R}$ & & & & .7732 \\
\hline$R$ square & & & & .6342 \\
\hline Adjusted R square & & & & .6231 \\
\hline$F$-value & & & & 10.65 \\
\hline Sig. & & & & 0.00 \\
\hline
\end{tabular}

\section{Dependent variable: $D A C$}

Significant at $\mathbf{. 0 5 \%}$

Where: DAC, discretionary accruals; ACSIZE, audit committee size; ACIND, audit committee independence; ACEXP, audit committee member's expertise; ACMT, audit committee meetings; AUQUL, audit quality; FISIZE, firm size; FLEV, financial leverage; CFO, cash flows from operating activities; and $\boldsymbol{\varepsilon}$, the error term.

The tests for $\mathrm{H} 4$ regarding the relationship between the number of audit committee meetings (ACMT) and earnings management, the result in Table 3 and 4 is supported this hypothesis (coefficient $=-0.385$ and $p<$ 0.05). This result may support the argument that the number of audit committees meetings does not significantly enhance the quality of financial reporting. However, although no statistically significant relationship is detected, a negative directional sign of the coefficient is observed. This result is similar to that of Davidson et al., (2005) who report an insignificant relationship between the number of audit committee meetings and earnings management. Additionally, AbdulRahman and Ali, (2006) find insufficient evidence for a negative relationship between earnings management and the frequency of audit committee meetings.

Finally, The H5 states that there is a significantly negative association between audit quality (AUQUL) and occurrence of earnings management. As shown in Table 3 and 4, this hypothesis is supported (coefficient = 0.472 and $\mathrm{p}<0.05)$. This is consistent with prior studies those examine the relation between auditor size and total discretionary accruals based on the modified Jones (1991) model. Francis \& Yu (1999) find that firms which hire a Big 5 auditors report lower discretionary accruals, consistent with Big Five auditors constraining opportunistic reporting of accruals. Also, Maijoor \& Vanstraelen, (2006) find that companies with non-Big 5 auditors (a proxy for lower audit quality) report discretionary accruals that significantly increase income compared to companies with Big 5 auditors.

Table 3, 4 also, show results from control variables, firm size as measured by the natural log of total assets has a significant positive effect on earnings management which corroborate the positive accounting theory's claim that large firms face greater scrutiny from investors, and thus more likely to manage earning to satisfy their forecasts. Financial leverage measured by debt-to-assets ratio, the result indicates that there is a negative and significant relationship. Also, the result shows that cash flow from operation activity is significantly and negatively related with the earnings management indicator. This finding is consistent with the notion that CFO influences the magnitude of the discretionary accruals. 


\section{Conclusion and Limitation}

The role of audit committees and audit quality in ensuring the quality of corporate financial reporting has come under considerable scrutiny due to recent high-profile earnings management cases in the world. Empirical evidences on the effect of audit committee effectiveness and audit quality on the occurrence of earnings management is rather inconsistent. Also, there has so far been relatively little or no research into earnings management practices in Egypt (Kamel \& Elbana, 2012). The multi-cultural roots of Egyptian society make it different from other societies and hence distinguish it as a setting for this study. Therefore, the purpose of this paper is to examine the association between the audit committee effectiveness, audit quality and earnings management practices of more active 50 Egyptian companies listed on the Egyptian Stock Exchange of the nonfinancial sector during the period 2007-2010.

After controlling for size, leverage and cash flow from operation activities, the results of univariate and multivariate analyses indicated that audit committees independence; experience of audit committee members; audit committee meetings; and audit quality have significant negative association with discretionary accruals as a proxy for earnings management. On the other hand, no significant relationship is found between audit committees size and the level of discretionary accruals. This paper is important because it offers useful information that is of great value to policy makers, academics and other stakeholders.

As with any research, limitation of the study is that this study is using a small sample of 40 companies. This sample may be small in size and, by construction, composed of the most active Egyptian listed companies and thus may not be representative of the population of Egyptian firms, consequently, caution should be considered in evaluating the results. Thus, it might have been better to look at companies from a wider range.

\section{References}

Abbott, L. J., Park, Y. \& Parker, S. (2000), "The effects of audit committee activity and independence on corporate fraud”, Managerial Finance, 26 (11), 55-67.

Abbott, L., Parker, S. \& Peters, G. (2004), "Audit committee characteristics and restatements", Auditing: A Journal of Practice \& Theory 23, 69-87.

Abd-Elsalam, O., \& Weetman, P. (2003), "Introducing International Accounting Standards to an Emerging Capital Market: Relative Familiarity and Language effect in Egypt", Journal of International Accounting, Auditing \& Taxation.12, 63-84.

Abdul Rahman, R., \& Ali, F. (2006), "Board, Audit Committee, Culture And Earnings Management: Malaysian Evidence", Managerial Auditing Journal 21(7), 783-804.

Ahsen, H. (2011), "Audit firm industry specialization and audit outcomes: Insights from academic literature", Research in Accounting Regulation 23(1), 114-129.

Balsam, S., Krishnan, J. \& Yang, J. (2003), “Auditorindustry specialization and earnings quality", Auditing: A Journal of Practice \& Theory 22(2), 71-97.

Beasley, M. S., Carcello, J. V., Hermanson, D. R. \& Lapides, P. D. (2000), "Fraudulent financial reporting: consideration of industry traits and corporate governance mechanisms", Accounting Horizons 14 (4),441-54.

Beasley, S. (1996), "An empirical analysis of the relation between board of directors composition and financial statement fraud", The Accounting Review 71, 443-65.

Bédard, J., Chtourou, S. H. \& Courteau, L. (2004), “The effect of audit committee expertise, independence, and activity on aggressive earnings management", Auditing: A Journal of Practice \& Theory 23, 13-35.

Blue Ribbon Committee on Improving the Effectiveness of Corporate Audit Committees (BRC) (1999), Report and Recommendations of Blue Ribbon Committee on Improving the Effectiveness of Corporate Audit Committees, New York and Washington, DC: NYSE and NASD.

Bowerman, B. L., \& O'Connell, R. T. (1990). Linear statistical models: An applied approach, 2nd ed. Belmont, CA: Duxbury.

Bryman, A., \& Cramer, D. (1997). Quantitative data analysis with SPSS for windows. London: Routledge.

Burrowes, A., \& Hendriks, A. (2005), "Independent Financial Experts: From Wished For to Wistful Thinking", Managerial Finance 31(9),52.

Carcello, J. V. \& Neal, T. L. (2003), "Audit committee independence and disclosure: choice for financially distressed firms", Corporate Governance 11(4), 289-99.

Chen, K. Y., Lin, K-L. \& Zhou, J. (2005), “Audit quality and earnings management for Taiwan IPO firms", Managerial Auditing Journal 20 (1), 86-104. 
Choi, J. H., Kim, C., Kim, J. B. \& Zang, Y. (2010), “Audit office size, audit quality, and audit pricing”, Auditing, A Journal of Practice \& Theory 29(1), 73-97.

Choi, J., Jeon, K. \& Park, J. (2004), "The role of audit committees in decreasing earnings statement: Korean evidence", International Journal of Accounting, Auditing \& Performance Evaluation 1(1), 37-60.

Collins, D., \& Hribar, P. (2002), "Errors in Estimating Accruals: Implications for Empirical Research", Journal of Accounting Research 40 (1), 105-135.

Craswell, A.T., Francis, J.R., \& Taylor, S.L. (1995), "Auditor Brand Name Reputations and Industry Specializations", Journal of Accounting and Economics 20, 297-322.

Davidson, R., Goodwin-Steward, J. \& Kent, P. (2005), "Internal governance structures and earnings management”, Accounting and Finance 45, 241-67.

Dechow, P. M., \& Skinner, D. J. (2000), "Earnings management: Reconciling the views of accounting academics, practitioners and regulators", Accounting Horizons 14(2), 235-250.

Dechow, P., Sloan, R., \& Sweeney, A. (1996), "Causes and Consequences of Earnings Manipulation: An Analysis of Firms Subject to Enforcement Actions by the SEC", Contemporary Accounting Research 13, 1-36.

DeZoort, F. T. \& Salterio, S. E. (2001), "The effects of corporate governance experience and financial reporting and audit knowledge on audit committee directors' judgments", Auditing: A Journal of Practice \& Theory 20, 3148.

DeZoort, F. T., Hermanson, D. R. \& Houston, R. W. (2003), "Audit committee support for auditors: the effects of materiality justification and accounting precision", Journal of Accounting and Public Policy 22, 175-99.

Ebrahim, A. (2007), "Earnings Management and Board Activity: An Additional Evidence", Review of Accounting and Finance 6 (1), 42-58.

Francis, J. R., \& Yu, M. D. (2009), "Big 4 office size and audit quality”, The Accounting Review 84 (5), 1521 1552.

Goncharov, I. (2005), "Earnings Management and its Determinants: Closing Gaps in Empirical Accounting Research" (Frankfurt am Main: Peter Lang).

Healy, P. M. \& Wahlen, J. M. (1999), "A review of the earnings management literature and its implications for standard setting", Accounting Horizons 13 (4), 365-83.

Jensen, M. C. (1993), "The modern industrial revolution, exit, and the failure of internal control systems", The Journal of Finance 48(3), 831-80.

Jiang, W., Lee, P., and Anandarajan, A. (2008), “The Association between Corporate Governance and Earnings Quality: Further Evidence using the GOV-Score”, Advances in International Accounting 24, 191-201.

Johari, N., Saleh, N., Jaffer, R., \& Hassan, M. (2008), "The Influence of Board Independence, Competency and Ownership on Earnings Management in Malaysia", Int. Journal of Economics and Management 2 (2), 281-306.

Jones, J. J. (1991), "Earnings management during import relief investigations", Journal of Accounting Research 29 (2), 193-226.

Kamel. H. \& Elbana, S. (2012), "Investigating the phenomenon of earnings management in the Egyptian stock market", Corporate Governance 12(3), 337-352.

Klein, A. (2002), "Audit committee, board of director characteristics and earnings statement", Journal of Accounting \& Economics 33, 375-400.

Krishnan, G. V. (2003), "Audit quality and pricing of discretionary accruals", Auditing: A Journal of Practice \& Theory 22 (1), 109-26.

Lin, J., Li, J. \& Yang, J. (2006), “The effect of audit committee performance on earnings quality”, Managerial Auditing Journal 21(9), 921-33.

Lin, W., \& Hwang, I. (2010), "Audit Quality, Corporate Governance, and Earnings Management: A MetaAnalysis", International Journal of Auditing 14, 57-77.

Loomis, C.J. (1999), “Lies, Damned Lies, and Managed Earnings”, Fortune 140 (2), 74-92.

Maijoor, S. J. \& Vanstraelen, A. (2006), "Earnings management within Europe: the effects of member state audit environment, audit firm quality and international capital markets", Accounting and Business Research 36 (1), 3352.

Mansi, S. A., Maxwell, W. F. \& Miller, D. P. (2004), "Does Auditor Quality and Tenure Matter to Investors? Evidence from the Bond Market", Journal of Accounting Research.42 (4), 755-793.

Meek, K.J., Roa, P.R. \& Skousen, J.C. (2007), "Evidence on factors affecting the relationship between CEO stock option compensation and earnings management", Review of Accounting and Finance 6 (3), 304-323.

Menon, K. \& Williams, J. D. (1994), "The use of audit committees for monitoring", Journal of Accounting and Public Policy 13 (2), 121-39. 
Metawee, A., (2013), “The relationship between characteristics of audit committee, board of directors and level of earning management, Evidence from Egypt”, Journal of International Business and Finance, Plymouth Business School, UK, January.

Neter, J., Wasserman, W., \& Kutner, M. H. (1989), Applied linear regression models, 2nd edition Homewood, III: Richard D. Irwin.

Park, Y. W. \& Shin, H. (2004), "Board composition and earnings management in Canada", Journal of Corporate Finance 10, 431-57.

Peasnell, K. V., Pope, P. F. \& Young, S. (2005), "Board monitoring and earnings management: Do outside directors influence abnormal accruals?", Journal of Business Finance \& Accounting 32 (7 \& 8), 1311-1346.

Piot, C. and Janin, R. (2007), "External auditors, audit committees and earnings management in France", European Accounting Review 16 (2), 429-54.

Schipper, K. (1989), “Commentary on earnings management”, Accounting Horizons 3, 1-102.

Securities and Exchange Commission (SEC) (2003), Strengthening the Commission's Requirements Regarding Auditor Independence. Washington, DC: SEC.

Shah, S., Nousheen, Z., \& Tahir, D. (2009), "Board Composition and Earnings Management an Empirical Evidence Form Pakistani Listed Companies", Middle Eastern Finance and Economics 3, 28-38.

Siregar, S.V., \& Utama, S. (2008), "Type of Earnings Management and The Effect of Ownership Structure, Firm Size, and Corporate-Governance Practices: Evidence From Indonesia”, The International Journal of Accounting 43: pp. 1-27.

Weber, M. (2006), "Sensitivity of executive wealth to stock price, corporate governance and earnings management", Review of Accounting and Finance 5 (4), 321-54.

Wild, J. J. (1996), "The audit committee and earnings quality", Journal of Accounting, Auditing \& Finance 11(2), 247-76.

Xie, B., Davidson, W. N. \& DaDalt, P. J. (2003), "Earnings management and corporate governance: the roles of the board and the audit committee", Journal of Corporate Finance 9, 295-314.

Yang, J. S. \& Krishnan, J. (2005), “Audit committees and quarterly earnings management”, International Journal of Auditing 9, 201-19.

Yermack, D. (1996), "Higher Valuation of Companies with a Small Board of Directors", Journal of Financial Economics 40 (2), 185-211. 